\title{
철결핍빈혈의 치료
}

전북대학교 의학전문대학원 종양혈액내과학교실

임호영 - 곽재용

\section{Treatment of Iron-Deficiency Anemia}

\author{
Ho-Young Yhim and Jae-Yong Kwak \\ Division of Hematology and Medical Oncology, Department of Internal Medicine, \\ Chonbuk National University Medical School, Jeonju, Korea
}

\section{서 론}

철결핍빈혈(iron-deficiency anemia)은 내과 외래 진료 시 가 장 흔히 발견되는 빈혈이다. 철은 헴(heme) 생성을 위한 필수 미량 유기물로서, 철 결핍은 헴 생성감소를 유발하고, 이는 혈색소(hemoglobin)의 생성 장애를 일으켜, 결과적으로 적혈 구의 크기가 감소되는 소적혈구빈혈(microcytic anemia)을 초 래한다. 국내 철결핍빈혈의 유병률은 국민건강영양조사 자료 (2010)의 보고에 따르면 남성에서 $0.7 \%$, 여성에서 $8.0 \%$ 로 여 성에서 월등히 높았고, 특히 가임기 여성에서는 $11.5 \%$ 이었 다[1]. 또 빈혈은 동반되지 않았지만 철결핍 상태에 있는 인 구의 비율도 가임기 여성의 $31.4 \%$ 에서 확인되어 상당수의 여 성에서 철결핍 상태에 있음을 확인할 수 있어 공중보건 면 에서도 관심의 대상이 되는 질환이라 하겠다. 또, 60 세 이상 의 고령자를 대상으로 한 다른 국내연구에서는 철결핍빈혈의 유병률이 남성(10.2\%), 여성(14.1\%)으로 비교적 높은 편이었 고, 더구나 연령이 증가함에 따라 남녀 모두에서 유병률이 증 가하는 소견을 보여[2] 우리 사회의 빠른 고령화를 고려하면 추후에도 중요한 건강 이슈가 될 것으로 판단된다. 따라서
본 장에서는 비교적 흔한 질환인 성인에서의 철결핍빈혈의 임상적 특징, 진단 및 치료에 대해서 간단히 알아보고자 한다.

\section{철 대사}

정상 성인은 몸에 약 3-5 g의 철을 가지고 있고, 이 중 약 $2 / 3$ 정도는 혈색소 내에 존재하며, 나머지는 저장철인 페리틴 (ferritin), 헤모시데린(hemosiderin)의 형태로, 또는 근육내의 미오글로빈(myoglobin) 형태로 보관되어 있다. 철은 십이지장 및 상부 공장(jejunum)에서 주로 흡수되며, 하루 1-2 mg 정도 가 음식물을 통해 흡수된다. 인체는 효과적으로 철을 배설하 는 수단이 없어 매일 1-2 mg 정도의 철만이 피부 및 상피세 포의 탈락에 의해 비특이적으로 소실되며, 인체 내에 흡수된 대부분의 철은 망상내피계의 대식세포를 통해 재활용된다. 따라서 철의 항상성 유지에는 철 흡수의 조절이 중요하며, 이러한 철 흡수는 인체내 철 저장량, 저산소증 유무, 적혈구 생성 속도에 의해 영향을 받는다. 음식물에 철은 헴철(heme iron)과 비헴철(non-heme iron)로 존재하며 이들은 서로 다른 기전을 통해 흡수된다[3]. 우선 혈색소나 미오글로빈에서 유

Correspondence to Jae-Yong Kwak, M.D., Ph.D.

Division of Hematology and Medical Oncology, Department of Internal Medicine, Chonbuk National University Medical School, 20 Geonji-ro, Deokjin-gu, Jeonju 561-712, Korea

Tel: +82-63-250-1791, Fax: +82-63-254-1609, E-mail: jykwak@jbnu.ac.kr 
- The Korean Journal of Medicine: Vol. 89, No. 1, 2015 -

래하는 헴철은 다른 음식에 의해 영향을 받지 않고, 철-포르 피린(iron-porphyrin) 화합물로 흡수된다. 헴철은 전체 음식중 에서는 약 $10 \%$ 전후에 불과하지만, 흡수되는 철의 양은 우리 몸의 $1 / 3$ 정도를 차지한다. 비헴철은 십이지장에서 ferric reductase에 의해 2가 철로 환원된 후, divalent metal transporter 1 을 통해 상피세포로 흡수되며, 이후 상피세포의 기저측면 막(basolateral membrane)에 존재하는 ferroportin이라는 전달체 (transporter)를 통해 혈장내로 전달된다. Ferroportin에는 hepcidin에 대한 수용체가 존재하며, 이들의 상호작용은 철 흡수 를 조절하는 중추 역할을 담당한다. 체내 철분이 과잉인 경 우에는 간세포에서 hepcidin 생성이 증가되어 ferroportin을 통 한 철 흡수를 억제하고, 철분이 부족한 경우에는 hepcidin 생 성을 억제하여 철 흡수를 증가한다. 이렇게 흡수된 철은 트랜 스페린(transferrin)과 결합되어 안정상태에서 운반되어 혈색 소 합성 등에 이용되며, 초과되는 철은 저장 단백인 아포페리 틴(apoferritin)과 결합하여 페리틴을 형성한다.

\section{철결핍빈혈의 원인}

\section{만성 실혈}

만성적인 실혈이 있으면 이에 따라 철분 손실이 발생한다 (Table 1). 가임기 젊은 여성에서 흔히 관찰되는 원인으로, 특 히 저체중 여성에서는 식이 철 부족까지 동반되는 경우가 많 다. 하지만 간혹 잠재성 출혈(occult bleeding)과 연관된 경우 가 있는데, 이러한 잠재성 출혈은 주로 위장관에서 발생하며, 암과 연관되는 경우도 있다. 국내의 한 연구에서 외래진료 중 철결핍빈혈로 진단된 환자의 $6.2 \%$ 에서 암이 발견되었는데, 이 중 폐경 전 여성에서는 $1.6 \%$ 인 것에 비해 폐경 후 여성과 남성에서 각각 $16 \%$ 와 $28.8 \%$ 에서 발견됨을 보고하였다[4]. 따
라서 철결핍빈혈 환자에서는 위장관 잠재성 출혈을 스크리닝 하기 위한 대변 잠혈 반응 검사, 위/대장 조영 검사 또는 내 시경 검사가 필요하며, 특히 위장관 잠재성 출혈은 간헐적으 로 발생할 수 있으므로 비록 대변 잠혈 반응 검사에서 음성 이더라도, 특히 폐경 후 여성과 남성에서는 위/대장 조영 검 사 또는 내시경 검사를 시행하는 것이 필요하겠다. 이외에도 위장관 출혈의 흔한 원인으로는 소화궤양, 위염, 식도정맥류, 대장 게실, 용종, 혈관형성이상(angiodysplasia) 등이 있다.

\section{흡수 이상}

만성 실혈에 비해 흡수 이상이 원인인 경우는 철결핍빈혈 에서는 비교적 드물다(Table 1). 하지만 위 절제 및 우회로 수술을 시행한 경우 철이 주로 십이지장 및 상부 공장에서 흡수되기 때문에 발생할 수 있다. 최근 철 흡수에서 hepcidin 의 역할을 이해하게 되면서, 유전적 요인으로 철 흡수가 되지 않는 iron-refractory iron deficiency anemia (IRIDA)라는 새로 운 질환이 확인되었다. 임상적으로는 철결핍빈혈이지만 경구 철분제 치료에 반응하지 않는 것이 특징인데, 이는 hepcidin 의 발현을 억제하는 TMPRSS6 유전자의 이상으로 비정상적 으로 hepcidin치가 상승하고, 이로 인해 철 흡수가 되지 않는 것과 연관된다[5]. 이러한 경우는 경정맥 철분 요법을 시행하 면 빈혈이 호전된다.

만성 신질환 환자에서는 전신적 염증에 의해 hepcidin 치가 상승하여 철 흡수에 장애가 동반되어 철결핍빈혈이 자주 관 찰될 수 있다. 또, 심한 근력운동을 하는 운동선수들에서도 철 결핍빈혈이 자주 발견된다[6]. 이는 운동 시 용혈에 따른 소 변 및 땀을 통한 철분 소실과 함께 신체 운동에 따른 염증반 응으로 혈중 hepcidin치가 상승하여 철분 흡수가 저하되는 것 이 원인으로 알려져 있다. 또 위산에 의해 비헴철이 환원되

\section{Table 1. Common cause of iron deficiency anemia}

\begin{tabular}{ll}
\hline Causes & \\
\hline Chronic blood loss & $\begin{array}{c}\text { Gastrointestinal (peptic ulcer, gastritis, esophageal varix, diverticulitis, inflammatory bowel disease, } \\
\text { hemorrhoid, angiodysplasia) and genitourinary (menorrhagia, intravascular hemolysis) } \\
\text { Drugs (non-steroidal anti-inflammatory drugs, salicylates, anticoagulants) }\end{array}$ \\
Impaired iron absorption & Gastrectomy (partial or total), inflammatory bowel disease, autoimmune atrophic gastritis, \\
& Helicobacter pylori infection \\
& Iron-refractory iron deficiency anemia (TMPRSS6 mutation) \\
& Drug (proton-pump inhibitors) \\
Increased iron requirement & Rapid growth (adolescence), pregnancy (2nd and 3rd trimester) \\
Others & Erythropoiesis stimulating agents use \\
& Chronic kidney disease (iron deficiency anemia result from chronic blood loss during dialysis and \\
& impaired absorption associated with systemic inflammation conditions) \\
\hline
\end{tabular}


어 흡수되는데, 장기간의 프로톤 펌프 억제제를 복용하면 지 속적으로 위산생성이 감소되어 철 흡수 장애가 발생할 수 있 는 점도 간과하지 말아야 하겠다.

\section{철결핍빈혈의 증상 및 징후}

철결핍빈혈의 특징적인 증상이나 징후보다는 위약감, 두 통, 만성적인 피로와 같은 빈혈에 의한 일반적인 증상 및 징 후가 주로 나타난다. 하지만 철결핍빈혈이 장기간 지속되는 경우 숟가락모양 손톱(spoon nail)과 같은 손발톱 이상 및 탈 모가 있을 수 있으며, 혀의 통증과 같은 증상이 있을 수 있 다. 특히 혀의 통증이 있으면서 빈혈이 있는 경우는 비타민 $\mathrm{B} 12$ 결핍에 의한 거대적혈모구 빈혈과 장기간의 철결핍빈혈 에서만 관찰됨을 기억해야겠다.

\section{철결핍빈혈의 검사소견}

특징적으로 소적혈구 저색소빈혈(microcytic hypochromic anemia)이 관찰된다. 전형적인 경우 일단 빈혈이 있으면서 mean cell volume $(\mathrm{MCV})$ 이 $80 \mathrm{fL}$ 이하, mean cell hemoglobin $(\mathrm{MCH})$ 이 $27 \mathrm{fL}$ 이하로 감소하고, 망상적혈구(reticulocyte)도 역시 감소한다. 혈청 철은 감소하나, 총철결합능은 증가하여, 결과적으로 트랜스페린 포화도(transferrin saturation)는 $20 \%$ 미만으로 감소한다. 혈청 페리틴 치는 골수 내 저장철의 양을 대표할 수 있는 지표로 철결핍빈혈의 확진에 사용될 수 있다. 철결핍빈혈이 있는 경우 혈청 페리틴치는 대개 $15 \mu \mathrm{g} / \mathrm{L}$ 미만 으로 감소한다. 하지만 다수의 기저 질환이 있는 환자에서 만성 질환에 의한 빈혈(anemia of chronic disease)이 동반된 경 우에는 트랜스페린이 증가하지 않아 총철결합능이 정상일 수 있으며, 또한 급/만성 염증이 동반된 경우에는 철결핍빈혈이 있음에도 혈청 페리틴 치가 정상범위일 수 있음을 기억해야 겠다. 철결핍빈혈, 만성 질환에 의한 빈혈 시의 혈액검사 소 견을 표 2에 간략히 정리하였다.
만성 질환에 의한 빈혈 외에 감별해야 질환으로는 지중해 성 빈혈(thalassemia)이 있다. 최근 동남아시아 지역 여성의 이 주 증가에 따라 향후 더욱 증가할 것으로 기대된다. 지중해 성 빈혈은 헤모글로빈의 글로빈(globin) 체인 생성 이상이 있 는 유전 질환으로 철결핍빈혈과 같이 검사소견상 소적혈구 성 저색소성 빈혈 소견을 보이나, 페리틴 및 트랜스페린 포화 도가 정상인 점에서 구분될 수 있다. 지중해성 빈혈은 혈색소 전기영동 검사(hemoglobin electrophoresis)를 통해 진단할 수 있다.

\section{철결핍빈혈의 치료}

철결핍빈혈의 치료는 원인 질환의 교정과 함께 적절한 용 량의 철분제를 충분한 기간 동안 투여하는 것이 중요하다 [6,7]. 철분 보충 시 경구 철분제의 투여는 안전하며 효과적 이므로 우선적으로 고려된다. 현재 국내에서 시판중인 경구 철분제에는 ferrous sulfate, polysaccharide iron complex, iron protein succinylate, ferric hydroxide poly maltose, carbonyl iron 등이 있는데, 이 중 용해도가 좋고 흡수가 우수한 ferrous sulfate 제제가 1 차적으로 많이 사용되고 있다. 경구 복용 시 용량은 절대 철(elemental iron)을 기준으로 하루 $150-200 \mathrm{mg}$ 을 2-3회 에 나눠 식간에 분복한다. 현재 국내에서 사용되는 ferrous sulfate제제에는 대표적으로 feroba-U ${ }^{\mathrm{TM}}(256 \mathrm{mg}$, 절대 철 80 $\mathrm{mg}$ ), hemocontin ${ }^{\mathrm{TM}}$ (절대 철 $100 \mathrm{mg}$ ) 등이 있으며, 이들 약제 2-3 T를 2-3회 분복하여 치료효과를 얻을 수 있다. 철분제의 복용 시 음식과 함께 복용할 경우 철분 흡수가 방해되므로, 약제 복용 전/후 2 시간 정도는 공복을 유지하는 것이 필요하 다. 또한 제산제, $\mathrm{H} 2$ 억제제, 프로톤 펌프 억제제와 같은 위 장약이나 칼슘제제, quinolone과 tetracycline 같은 항생제, 우 유 및 커피도 철분 흡수를 억제하므로 주의가 필요하다. 경 구 철분제의 주요 부작용은 복부 팽만감, 복통, 변비, 설사와 같은 위장 장애이며, 이는 대개 복용하는 절대 철의 양과 비 례한다. 따라서 위장장애가 심한 경우 저용량부터 서서히 증

Table 2. Laboratory results of iron deficiency anemia, anemia of chronic disease, or both

\begin{tabular}{lccc}
\hline & Iron deficiency anemia & Anemia of chronic disease & Both conditions \\
\hline Iron & Reduced & Reduced & Reduced \\
Total iron binding capacity & Increased & Reduced to normal & Reduced \\
Transferrin saturation & Reduced & Reduced & Reduced \\
Ferritin & Reduced & Normal to increased & Reduced to normal \\
Soluble transferrin receptor & Increased & Normal & Normal to increased \\
\hline
\end{tabular}


- 대한내과학회지: 제 89 권 제 1 호 통권 제 659 호 2015 -

Table 3. Intravenous iron preparations available in Korea

\begin{tabular}{lc}
\hline Agents & Typical replacement dose \\
\hline Iron sucrose & $\begin{array}{c}200 \mathrm{mg} \text { over } 15-60 \mathrm{~min}, 300 \mathrm{mg} \text { over } 1.5 \mathrm{hr} \text {, or } 500 \mathrm{mg} \text { over } 4 \mathrm{hr} \text {; repeat 1-2 times per week for } \\
\text { total dose of } 1,000-1,500 \mathrm{mg}\end{array}$ \\
Ferric carboxymaltose & $500 \mathrm{mg}$ over $15-30 \mathrm{~min}$; repeat 1 session per week for total dose of $1,000-1,500 \mathrm{mg}$ \\
\hline
\end{tabular}

량하면서 증상을 관찰하는 것도 한 가지 방법이다. 적절한 철 분제 치료 시 치료 후 약 2-3일부터 증상이 좋아지고, 1주경 부터 망상적혈구의 상승이 있으며, 치료 2주째부터는 혈색소 의 상승이 있고, 약 6-8주경에는 혈색소가 정상으로 회복된 다. 빈혈이 교정된 후에도 골수 내 저장 철이 충분히 축적되 도록 약 6-12개월 정도 추가로 철분제를 복용하도록 한다.

경구 철분치료에 빈혈이 적절한 반응을 보이지 않는 경우 가 있는데, 이때는 원래 진단이 잘못된 경우(thalassemia, 만성 질환에 의한 빈혈 등), 철분제 복약 순응도가 낮은 경우, 지속 적인 실혈이 계속되고 있는 경우 등이다. 하지만 경구 철분 제를 잘 복용하는 데도 불구하고 적절한 반응을 보이지 않는 경우가 있는데, 특히 경구 철분제를 4-6주 정도 복용했음에도 혈색소치가 $1 \mathrm{~g} / \mathrm{dL}$ 이상 상승하지 않는 경우를 ‘불응성' 철결 핍빈혈로 정의한다[7]. 이러한 불응성 철결핍빈혈의 원인에 는 철 흡수에 영향을 주는 위절제 수술의 병력, 염증성 장질 환, 자가면역성 위축성 위염, 헬리코박터 균 감염 등과 같은 위장관 질환이 있는 경우와 선천적으로 TMPRSS6 유전자의 돌연변이에 의해 철분 흡수에 장애가 있는 IRIDA 등이 있다. 이러한 불응성 철결핍빈혈을 치료하는 내과 임상의로서 꼭 기억할 점은 이러한 불응성 철결핍빈혈의 상당수에서 경정맥 철분투여에 의해 빈혈이 호전될 수 있으므로, 경구 철분제에 반응이 없다고 해서 철결핍빈혈이 아니라고 판단해서는 안 된다는 점이다.

경정맥 철분 투여는 철 흡수 및 위장장애와 관련 없이 철 분을 공급하는 것이 장점이나, 아나필락시스와 같은 주입관 련 반응(infusion reaction)은 주의가 필요하다. 하지만 주입관 련 반응은 주로 고분자량 iron dextran 제제에서 발생하나 최 근 국내에 도입된 iron sucrose (venoferrum ${ }^{\mathrm{TM}}$ ), ferric carboxymaltose (ferinject ${ }^{\mathrm{TM}}$ )제제에서는 매우 드문 것으로 알려져 있 다. 그래서 투여 시 이전 iron dextran제제는 테스트 용량을 투여하여 주입관련 반응을 확인해야 했지만, iron sucrose 및 ferric carboxymaltose제제는 이러한 사용 전 테스트를 할 필요 가 없는 장점이 있다. 성인에서 iron sucrose제제는 1 일 최대 $500 \mathrm{mg}$, ferric carboxymaltose제제는 하루 최대 $1,000 \mathrm{mg}$ 까지 투여할 수 있으며, 총 투여량은 아래의 계산식에 따른 총 철
부족량을 계산한 후 이에 따라 개별적으로 적용할 수 있다.

총 철 부족량 $(\mathrm{mg})=$ 체중 $(\mathrm{kg}) \times($ 목표 혈색소 수치 - 환자 혈색소 수치 $)(\mathrm{g} / \mathrm{L}) \times 0.24+$ 저장철 양 $(\mathrm{mg})$

예를 들어, $60 \mathrm{~kg}$ 성인이 현재 헤모글로빈 $6 \mathrm{~g} / \mathrm{dL}(60 \mathrm{~g} / \mathrm{L})$ 로 경정맥 철분투여를 고려하는 경우, 목표 헤모글로빈 13 $\mathrm{g} / \mathrm{dL}(130 \mathrm{~g} / \mathrm{L})$, 저장 철 $500 \mathrm{mg}$ 정도를 계획한다면 총 1,508 $\mathrm{mg}$ 의 철을 투여해야 한다. 이를 위해서는 현재 국내의 iron sucrose제제들이 $20 \mathrm{mg} / \mathrm{mL}$ 이므로, 총 $75 \mathrm{~mL}$ 의 보충이 필요 함을 의미한다. 경정맥 철분제의 간략한 투여법 및 용량에 대해서는 표 3에 설명하였다.

철결핍빈혈의 치료를 목적으로 수혈은 일반적으로 권고되 지 않는다. 하지만 호흡곤란 등의 심혈관계 이상을 동반한 경우에 한해 수혈을 할 수 있으며, 이때에는 갑작스런 혈량 증가에 의해 심부전이 더욱 악화될 수 있으므로 매우 천천히 수혈해야 하겠다.

\section{결 론}

철결핍빈혈은 비교적 흔한 질환이며, 적절한 진단 및 치료 를 통해 증상 호전을 기대할 수 있다. 철결핍빈혈의 진단은 비교적 간단한 혈액 검사(일반혈액검사, 망상적혈구, 혈청 철 /총철결합능/페리틴)를 통해 진단할 수 있다. 하지만 만성 질 환에 의한 빈혈과 간혹 구분하기 어려운 경우들이 있으며, 최 근 이런 상황에서 soluble transferrin receptor 및 hepcidin의 역 할이 이 분야에서 주요한 관심의 대상이다. 또, 철결핍빈혈 환자에서는 암선별 검사가 필요하며, 최소한 남성과 폐경기 여성에서는 꼭 필요하다. 철결핍빈혈의 치료는 적절한 용량 의 철분제를 충분한 기간 동안 경구 투여하는 것이 원칙이다. 약제 복약 순응도 감소가 주요 치료 실패의 원인이므로 복 약 순응도(compliance)를 개선하기 위한 노력이 필요하며, 적 절한 투여에도 불구하고 경구 요법에 불응성이거나 경구 요 법에 불내성(intolerance)인 경우는 경정맥 철분투여가 필요 하다.

중심 단어: 철결핍빈혈; 헵시딘; 경구 요법; 경정맥 요법 


\section{REFERENCES}

1. Lee JO, Lee JH, Ahn S, et al. Prevalence and risk factors for iron deficiency anemia in the Korean population: Results of the Fifth Korea National Health and Nutrition Examination Survey. J Korean Med Sci 2014;29:224-229.

2. Choi CW, Park KH, Yoon SY, et al. Prevalence of anemia in the elderly. Korean J Med 2001;60:249-253.

3. Oliveira F, Rocha S, Fernandes R. Iron metabolism: from health to disease. J Clin Lab Anal 2014;28:210-218.
4. Kim SJ, Ha SY, Choi BM, et al. The prevalence and clinical characteristics of cancer among anemia patients treated at an outpatient clinic. Blood Res 2013;48:46-50.

5. Finberg KE, Heeney MM, Campagna DR, et al. Mutations in TMPRSS6 cause iron-refractory iron deficiency anemia (IRIDA). Nat Genet 2008;40:569-571.

6. DeLoughery TG. Microcytic anemia. N Engl J Med 2014; 371:1324-1331.

7. Camaschella C. Iron-deficiency anemia. N Engl J Med 2015; 372:1832-1843. 